\title{
Regulation of Chrysanthemum Growth by Spectral Filters
}

\author{
Nihal C. Rajapakse and John W. Kelly \\ Department of Horticultural Sciences, Clemson University, Clemson, SC 29634 \\ Additional index words. Dendranthema $\times$ grandiflorum, ornamental plants, photomorphogenesis, gibberellic acid, \\ Chrysanthemum morifolium
}

\begin{abstract}
The role of light quality and quantity in regulating growth of vegetative Dendranthema $\times$ grandiflorum (Ramat.) Kitamura was evaluated using $\mathrm{CuSO}_{4}$ solutions and water (control) as spectral filters. Copper sulfate filters increased the red $(R)$ : far-red $(F R)$ and the blue $(B): R$ ratios $(R=600$ to $700 \mathrm{~nm} ; F R=700$ to $800 \mathrm{~nm} ; B=400$ to 500 urn) of transmitted light. Photosynthetic photon flux (PPF) under 4\%, $8 \%$ and $16 \% \mathrm{CuSO}_{4}$ filters was reduced $26 \%, 36 \%$, and $47 \%$, respectively, from natural irradiance in the greenhouse, which averaged $\approx 950 \mu \mathrm{mol} \cdot \mathrm{m}^{-2} \cdot \mathrm{s}^{-1}$. Control treatments were shaded with Saran plastic film to ensure equal PPF as the corresponding $\mathrm{C} \mathrm{uSO}_{4}$ chamber. Average daily maxima and minima were $26 \pm 3 \mathrm{C}$ and $16 \pm 2 \mathrm{C}$. At the end of the 4-week experimental period, average height and internode length of plants grown under $\mathrm{CuSO}_{4}$ filters were $\approx 40 \%$ and $34 \%$ shorter than those of plants grown under control filter. Reduction in plant height and internode length was apparent within 1 week after the beginning of treatment. Total leaf area (LA) was reduced by $32 \%$ and leaf size (LS) was reduced by $24 \%$ under $\mathrm{CuSO}_{4}$ filters. Specific leaf weight (SLW) was higher under $\mathrm{CuSO}_{4}$ filters than for the controls. Irradiance transmitted through $\mathrm{CuSO}_{4}$ filters reduced fresh and dry leaf weights by $30 \%$. Fresh and dry stem weights of plants grown under $\mathrm{CuSO}_{4}$ filters were $60 \%$ lower than those of controls. Relative dry matter accumulation into leaves was increased in plants grown under $\mathrm{CuSO}_{4}$ filters while it was reduced in stems. A single application of $\mathbf{G A}_{3}$ before irradiation partially overcame the height reduction under $\mathrm{CuSO}_{4}$ filters, suggesting GA biosynthesis/action may be affected by light quality. Our results imply that alteration of light quality could be used to control chrysanthemum growth as an alternative method to conventional control by chemical growth regulators. Chemical names used: gibberellic acid (GA)
\end{abstract}

Chemical control of plant height is used extensively in ornamental plant production. Due to perceived risks to humans and the environment, the use of some chemical growth regulators recently has been restricted.

Manipulation of temperature and light quality in greenhouses have been proposed as nonchemical methods for controlling plant height. Plant height was reduced when plants were grown with higher night than day temperatures in a wide range of plants, but leaf chlorosis and delay of flowering limit the use of temperature manipulation for plant growth regulation (Heins and Erwin, 1990).

The growth of many plant species can be altered by manipulating the amount of $R$ relative to FR irradiance without altering the amount of PPF (Mortensen and Strømme, 1987). R irradiation has been reported to inhibit stem elongation of maize (Zea mays L.) seedlings (Vanderhoef et al., 1979) and pea (Pisum sativum L.) (Noguchi and Hashimoto, 1990), promote lateral shoot growth of tomato (Lycopersicon esculentum Mill. cv. Amberley Cross) (Tucker, 1975), prevent dark-induced leaf abscission of mung bean [Vigna radiata (L.) Wilczek] (Decoteau and Craker, 1984) and increase the number of tillers in perennial rye grass (Lolium perenne L.) (Deregibus et al., 1983). The effects of FR irradiation have been shown to be the opposite of the effects of $\mathrm{R}$ irradiation (Smith, 1982).

Plant responses to $\mathrm{R}$ irradiation mimic some responses of chemical growth retardants (Starman et al., 1989; Wang and Gregg, 1989). Chemical growth retardant effects were mostly mediated through the inhibition of GA biosynthesis (Graebe, 1987). Although the mechanism of R-irradiation-induced inhibition of stem elongation is not known, the possible involvement

\footnotetext{
Received for publication 1 Apr. 1991. Accepted for publication 2 Dec. 1991 Technical contribution no. 3169 of the South Carolina Agricultural Experiment Station. The cost of publishing this paper was defrayed in part by the payment of page charges. Under postal regulations, this paper therefore must be hereby marked advertisement solely to indicate this fact.
}

of hormonal balance, specifically GA, has been suggested by many researchers (Campell and Bonner, 1986; Lockhart, 1964; Tucker and Mansfield, 1973). In contrast, Noguchi and Hashimoto (1990) reported that inhibition of stem elongation of pea seedlings when exposed to $\mathrm{R}$ irradiation did not result from action of GA but from unidentified endogenous growth inhibitors.

The objectives of the present study were to 1) investigate the use of light quality for regulating chrysanthemum ('Bright Golden Anne') growth using $\mathrm{CuSO}_{4}$ solutions as spectral filters; 2) determine the effects of reduced irradiance by increasing $\mathrm{CuSO}_{4}$ concentrations in the spectral filters; and 3) gain preliminary knowledge of the involvement of GA in the light quality-induced changes of chrysanthemum growth.

\section{Materials and Methods}

Plant material. Uniformly rooted 'Bright Golden Anne' chrysanthemum shoot cuttings with three to four leaves (Yoder Bros., Pendleton, S. C. $)$ were planted individually in $0.6-\mathrm{m}^{3}(0.11 \mathrm{~m}$ wide) square plastic pots containing a commercial potting mix (Mix 3B, Fafard, Anderson, S.C.). Plants were allowed to establish as single-stem plants in the greenhouse for 1 week before being subjected to the treatments in Expts. 1 and 2. All plants were fertilized throughout the experiment, once daily at irrigation, with $18 \mathrm{~N}-3.5 \mathrm{P}-5 \mathrm{~K}$ mM from Peter's $20-20-20$ fertilizer (W.R. Grace Co., Fogelsville, Pa.).

Effect of $\mathrm{CuSO}_{4}$ spectral filters on chrysanthemum growth (Expt. 1). After the establishment period, plants were transferred (Nov. 1989 and Jan. 1990) to six chambers (1.8 x 1.2 $\mathrm{m})$ roofed with polycarbonate panels with $6 \times 11-\mathrm{mm}$ channels (Polygal U. S.A., Janesville, Wis.). Polycarbonate panels were sealed at one end and filled with a $0 \%, 4 \%, 8 \%$, or $16 \%$ aqueous

Abbreviations: B, blue; FR, far red; LA, leaf area; LS; leaf size; R, red; SER, stem elongation rate; SLW, specific leaf weight. 
solution of $\mathrm{CuSO}_{4}-5 \mathrm{H}_{2} \mathrm{O}$. Three chambers with water-filled panels were used as controls. All chambers were placed inside a greenhouse to receive natural irradiance and photoperiod (average 10 $\mathrm{h}$ light and $14 \mathrm{~h}$ dark). Sidewalls of each chamber were covered inside with white and outside with black polyethylene to prevent transmission of unfiltered natural irradiance. A neutral shading material (Saran plastic film; Dow, Indianapolis) was used in each control chamber to ensure the same PPF level as in the corresponding $\mathrm{CuSO}_{4}$ chamber. Two fans located at opposite sides of each chamber circulated air within a chamber and prevented temperature increase. Average daily maxima inside 4\%, $8 \%$, and $16 \% \mathrm{CuSO}_{4}$ and corresponding control chambers were $28 \pm 4 \mathrm{C}, 26 \pm 3 \mathrm{C}$, and $25 \pm 3 \mathrm{C}$, and minima were $16 \pm$ $2 \mathrm{C}, 16 \pm 2 \mathrm{C}$, and $15 \pm 2 \mathrm{C}$, respectively.

Light quality. The spectral energy flux inside each treatment chamber was measured from 330 to $850 \mathrm{~nm}$ in $5-\mathrm{nm}$ steps at the beginning (day 0 ) and at the end (day 28) of the experiment with a LI-1800 spectroradiometer equipped with a LI-1800-10 remote cosine sensor (LI-COR, Lincoln, Neb.). All irradiance measurements were made between 1200 and 1400 HR on clear days. PPF was determined as the photon flux integral between 400 and $700 \mathrm{~nm}$ from spectroradiometer data. Reduction in PPF by each $\mathrm{CuSO}_{4}$ solution was calculated using irradiance in the greenhouse (outside chambers). PPF under $4 \%, 8 \%$, and $16 \%$ $\mathrm{CuSO}_{4}$ filters was reduced $\approx 26 \%, 36 \%$, and $47 \%$ of natural irradiance in the greenhouse, which averaged $\approx 950$ $\mu \mathrm{mol} \cdot \mathrm{m}^{-2} \cdot \mathrm{s}^{-1}$. Irradiance measurements made at the beginning and end of the experiments indicated that. the spectral quality and relative irradiance levels did not change significantly during the experimental period. Ratios of photon flux between wavelengths of 600 and $700 \mathrm{~nm}$ (R irradiance) and 700 and $800 \mathrm{~nm}$ (FR irradiance) (R : FR) and of photon flux between wavelengths of 400 and $500 \mathrm{~nm}$ (B irradiance) and 600 and $700 \mathrm{~nm}$ $[B: R]$ were calculated for irradiance transmitted through control and $\mathrm{CuSO}_{4}$ filters. Phytochrome photoequilibrium $\left(\phi=\mathrm{P}_{\mathrm{fr}}\right.$ $\left.: \mathrm{P}_{\text {to }}\right)$ under $\mathrm{CuSO}_{4}$ and control filters was estimated according to the method described by Sager et al. (1988).

Effect of exogenous $\mathrm{GA}_{3}$ and light quality on chrysanthemum growth (Expt. 2). At the end of the establishment period (Mar. 1990), plants were sprayed to runoff with $0,0.07$, or $0.14 \mathrm{~mm}$ $\mathrm{GA}_{3}$ (Pro-Gibb Plus, Abbott Laboratories, Chicago) before transfer to the chamber with a $4 \% \mathrm{CuSO}_{4}$ or a water (control) filter. Tween $20(0.1 \%)$ (Fisher Scientific, Fair Lawn, N.J.), a surfactant, was added to all spray treatments. Average daily maxima inside the $\mathrm{CuSO}_{4}$ and control chambers during the experiment were $31 \pm 4 \mathrm{C}$ and $32 \pm 4 \mathrm{C}$, and the minimum was $17 \pm 3 \mathrm{C}$ in both.

Data collection and analysis. Plant height (height from soil level to plant apex) and number of fully expanded leaves were measured weekly for 4 weeks in both experiments. Average internode length was calculated as plant height divided by number of leaves. SER was calculated using height data as the increase per week. Total LA (using a LI-3100 area meter, LICOR) and fresh and dry weights of stems (SFW and SDW) and leaves (LFW and LDW) were measured at the end of 4 weeks. For dry weight measurements, tissue was oven-dried at $85 \mathrm{C}$ for $48 \mathrm{~h}$. Chlorophyll content of the third or fourth fully expanded leaf from the apex was determined on five leaf disks $\left(0.28 \mathrm{~cm}^{2} /\right.$ disk) as described by Moran (1982) and Moran and Porath (1980), but only for Expt. 1.

Both experiments were conducted twice. In Expt. 1, six light treatments were randomly assigned to chambers with 10 singlestem plants per treatment. In Expt. 2, two light treatments were randomly assigned to chambers with five single-stem plants per treatment. Data were subjected to analysis of variance. Differences among treatment means were tested using Duncan's multiple range test or linear and quadratic functions, where appropriate.

\section{Results}

Light quality. Copper sulfate solution reduced $\mathrm{R}$ and FR wavelengths of transmitted irradiance compared with controls, but the reduction of FR was greater than that of R (Fig. 1). Copper sulfate at $8 \%$ reduced $\mathrm{R}$ relative to $4 \% \mathrm{CuSO}_{4}$ and almost eliminated FR. Irradiance passing through $\mathrm{CuSO}_{4}$ filters had higher $\mathrm{R}: \mathrm{FR}, \mathrm{B}: \mathrm{R}$, and $\mathrm{B}: \mathrm{FR}$ ratios than the control (water) filters (Table 1). Copper sulfate at $16 \%$ further reduced $\mathrm{R}$, thus reducing the $\mathrm{R}$ : FR ratio compared with $4 \%$ or $8 \%$ $\mathrm{CuSO}_{4}$ solutions. Estimated $\phi$ values for $\mathrm{CuSO}_{4}$ filters were higher than those for control filters and slightly decreased as $\mathrm{CuSO}_{4}$ concentration increased (Table 1).

Influence of $\mathrm{CUSO}_{4}$ filters on chrysanthemum growth. Plant height in the controls was similar for all three irradiance levels (Table 2). Average height of plants grown under $\mathrm{CUSO}_{4}$ filters was $\approx 40 \%$ shorter at the end of the experiment than that of plants grown under control filters (Table 2). Plants grown under $8 \% \mathrm{CuSO}_{4}$ filter were shorter than those grown under $4 \% \mathrm{CuSO}_{4}$ filter, but the height was similar for plants grown under $8 \%$ or $16 \% \mathrm{CuSO}_{4}$ filters. Plants grown under $\mathrm{CUSO}_{4}$ filters had slightly fewer leaves than control plants, but within $\mathrm{CuSO}_{4}$ or control treatment, number of leaves was similar. Average internode length of control plants was $50 \%$ longer than that of plants

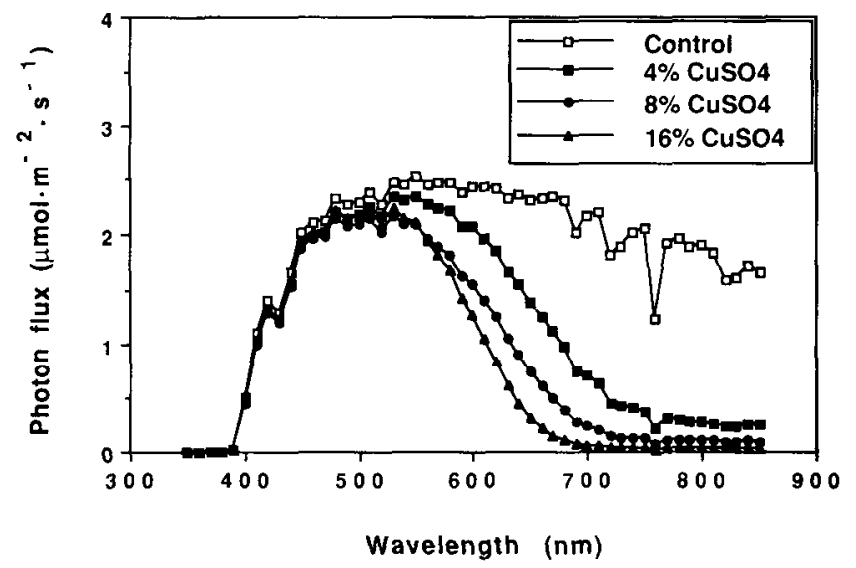

Fig. 1. Photon flux distribution of light transmitted through $\mathrm{CuSO}_{4}$ or control (water) filters.

Table 1. Influence of $\mathrm{CuSO}_{4}$ spectral filters on relative PPF, ratio of photon flux between different wavelengths $(B=400$ to $500 \mathrm{~nm}$; $R$ $=600$ to $700 \mathrm{~nm} ; \mathrm{FR}=700$ to $800 \mathrm{~nm}$ ) and estimated phytochrome photoequilibrium $(\phi)$. Control panels were filled with water and shaded with Saran plastic film to establish the same PPF as the corresponding $\mathrm{CuSO}_{4}$ chamber.

\begin{tabular}{cccccc}
\hline \hline $\begin{array}{c}\mathrm{CuSO}_{4} \\
\text { concn } \\
(\%)\end{array}$ & $\begin{array}{c}\text { PPF } \\
\text { reduction } \\
(\%)\end{array}$ & $\mathrm{R}: \mathrm{FR}$ & $\mathrm{B}: \mathrm{R}$ & $\mathrm{B}: \mathrm{FR}$ & $\phi$ \\
\hline 0 & 26 & 1.1 & 0.8 & 0.8 & 0.71 \\
& 36 & 1.1 & 0.9 & 1.1 & 0.72 \\
& 47 & 1.1 & 0.7 & 0.8 & 0.72 \\
4 & 26 & 3.1 & 1.7 & 5.1 & 0.79 \\
8 & 36 & 4.1 & 3.7 & 13.4 & 0.77 \\
16 & 47 & 2.6 & 4.4 & 10.7 & 0.75 \\
\hline
\end{tabular}


Table 2. Influence of light quality and irradiance on plant height, number of leaves, average internode length, and average SER of Dendranthema $\times$ grandiflorum 'Bright Golden Anne'. Measurements were taken 4 weeks after start of irradiation treatment.

\begin{tabular}{|c|c|c|c|c|c|}
\hline $\begin{array}{l}\mathrm{CUSO}_{4} \\
\text { concn }^{2} \\
\end{array}$ & $\begin{array}{c}\mathrm{PPF} \\
\text { reduction } \\
(\%)\end{array}$ & $\begin{array}{l}\text { Plant } \\
\text { ht } \\
(\mathrm{cm})\end{array}$ & $\begin{array}{l}\text { No. } \\
\text { leaves }\end{array}$ & $\begin{array}{l}\text { Internode } \\
\text { length }^{y} \\
{ }^{y}(\mathrm{~cm})\end{array}$ & $\begin{array}{c}\text { SER }^{\mathrm{y}} \\
\left(\mathrm{cm} \cdot \text { week }^{-1}\right) \\
\end{array}$ \\
\hline \multirow[t]{3}{*}{0} & 26 & $24.4 \mathrm{a}$ & $17 \mathrm{a}$ & $1.5 \mathrm{a}$ & $4.2 \mathrm{a}$ \\
\hline & 36 & $24.8 \mathrm{a}$ & $17 \mathrm{a}$ & $1.5 \mathrm{a}$ & $4.2 \mathrm{a}$ \\
\hline & 47 & $24.1 \mathrm{a}$ & $17 \mathrm{a}$ & $1.4 \mathrm{a}$ & $3.9 \mathrm{a}$ \\
\hline 4 & 26 & $16.1 \mathrm{~b}$ & $16 \mathrm{~b}$ & $1.0 \mathrm{~b}$ & $2.2 \mathrm{~b}$ \\
\hline 8 & 36 & $14.4 \mathrm{c}$ & $15 \mathrm{~b}$ & $0.9 \mathrm{~b}$ & $1.7 \mathrm{c}$ \\
\hline 16 & 47 & $15.2 \mathrm{c}$ & $15 \mathrm{~b}$ & $1.0 \mathrm{~b}$ & $1.8 \mathrm{c}$ \\
\hline
\end{tabular}

${ }^{2}$ See Table 1 for spectral characteristics.

'Each number is the mean of 20 plants. Mean comparison within a column by Duncan's multiple range test, $P=0.05$. Means with same letter are not significantly different.

Table 3. Influence of light quality and irradiance on total LA, average LS, SLW, leaf fresh weight (LFW), and stem fresh weight (SFW) of Dendranthema $\times$ grandiflorum 'Bright Golden Anne'. Measurements were taken 4 weeks after start of irradiation treatment.

\begin{tabular}{ccccccc}
\hline \hline $\begin{array}{c}\mathrm{CuSO}_{4} \\
\text { concn }^{2}\end{array}$ & $\begin{array}{c}\text { PPF } \\
\text { reduction } \\
(\%)\end{array}$ & $\begin{array}{c}\mathrm{LA}^{\mathrm{y}} \\
\left(\mathrm{cm}^{2}\right)\end{array}$ & $\begin{array}{c}\mathrm{LS}^{\mathrm{y}} \\
\left(\mathrm{cm}^{2}\right)\end{array}$ & $\begin{array}{c}\mathrm{SLW}^{\mathrm{y}} \\
\left(\mathrm{g} \cdot \mathrm{cm}^{-2}\right)\end{array}$ & $\begin{array}{c}\mathrm{LFW}^{\mathrm{y}} \\
(\mathrm{g})\end{array}$ & $\begin{array}{c}\mathrm{SFW}^{\mathrm{y}} \\
(\mathrm{g})\end{array}$ \\
\hline 0 & 26 & $610 \mathrm{a}$ & $33.5 \mathrm{a}$ & $0.033 \mathrm{~b}$ & $20.1 \mathrm{a}$ & $6.4 \mathrm{a}$ \\
& 36 & $633 \mathrm{a}$ & $33.6 \mathrm{a}$ & $0.034 \mathrm{~b}$ & $21.0 \mathrm{a}$ & $6.6 \mathrm{a}$ \\
& 47 & $605 \mathrm{a}$ & $33.4 \mathrm{a}$ & $0.033 \mathrm{~b}$ & $19.7 \mathrm{a}$ & $5.9 \mathrm{a}$ \\
4 & 26 & $456 \mathrm{~b}$ & $26.8 \mathrm{~b}$ & $0.036 \mathrm{a}$ & $16.2 \mathrm{~b}$ & $3.1 \mathrm{~b}$ \\
8 & 36 & $385 \mathrm{~b}$ & $24.0 \mathrm{c}$ & $0.035 \mathrm{a}$ & $13.4 \mathrm{c}$ & $2.4 \mathrm{c}$ \\
16 & 47 & $411 \mathrm{~b}$ & $25.7 \mathrm{bc}$ & $0.036 \mathrm{a}$ & $14.6 \mathrm{bc}$ & $2.1 \mathrm{bc}$ \\
\hline
\end{tabular}

${ }^{2}$ See Table 1 for spectral characteristics.

'Each number is the mean of 20 plants. Mean comparison within a column by Duncan's multiple range test, $P=0.05$. Means with same letter are not significantly different.

grown under $\mathrm{CuSO}_{4}$ filters at the end of the experiment (Table 2 ). There were no differences in internode length of plants within control or $\mathrm{CuSO}_{4}$ treatment.

SER of plants grown under $\mathrm{CuSO}_{4}$ filters was $\approx 50 \%$ less than that of control plants (Table 2). Decreased irradiance did not significantly reduce SER of plants grown under control filter, but under $\mathrm{CuSO}_{4}$ filters, decreased irradiance (at $8 \% \mathrm{CuSO}_{4}$ compared with $4 \% \mathrm{CuSO}_{4}$ ) reduced SER. SER was similar between $8 \%$ and $16 \% \mathrm{CuSO}_{4}$ treatments.

Plants grown under $\mathrm{CuSO}_{4}$ filters had a significantly lower LA $(32 \%)$ and average LS (LS = LA/number of leaves; $24 \%$ ), but higher SLW (9\%) (SLW = LFW/LA) than control plants (Table 3). Irradiance did not significantly affect LA or SLW in either control or $\mathrm{CuSO}_{4}$ treatment.

Irradiance transmitted through $\mathrm{CuSO}_{4}$ filters reduced LFW and SFW of plants compared with control plants (Table 3). However, the reduction in SFW was greater than that of LFW; i.e., SFW of plants grown under $\mathrm{CuSO}_{4}$ filters was reduced by $>50 \%$, while LFW was reduced by $\approx 30 \%$ compared with control plants.

Total shoot dry weight was reduced $(38 \%)$ when plants were grown under $\mathrm{CuSO}_{4}$ filters (Table 4). Plants grown under $\mathrm{CuSO}_{4}$ filters had lower leaf $(30 \%)$, stem $(59 \%)$, and root $(33 \%)$ (except in $4 \% \mathrm{CuSO}_{4}$ ) dry weights than those of control plants. Low irradiance resulted in decreased dry matter production in $\mathrm{CuSO}_{4}$ and control treatments.

The partitioning of shoot dry matter into leaves and stems was affected by the irradiance passing through $\mathrm{CuSO}_{4}$ filters
(Table 4 ). In control plants, $\approx 73 \%$ of total shoot dry matter accumulated into leaves and $27 \%$ into stems. Irradiance transmitted through $\mathrm{CuSO}_{4}$ filters reduced percent dry matter accumulation into stems from $27 \%$ to $18 \%$ and increased dry matter accumulation into leaves from $72 \%$ to $82 \%$ (Table 4 ).

Plants grown under $\mathrm{CuSO}_{4}$ filters were darker green and had a higher total chlorophyll content than the corresponding control plants (Table 5). Total chlorophyll content of plants grown under low irradiance (36\% or $47 \%$ PPF reduction) was lower compared with that of plants grown under high irradiance $(26 \% \mathrm{PPF}$ reduction) in both control and $\mathrm{CuSO}_{4}$ treatments. Total chlorophyll content was similar in plants grown at $36 \%$ or $47 \% \mathrm{PPF}$ under both spectral filters.

Influence of exogenous $\mathrm{GA}_{3}$ and light quality on chrysanthemum growth. $\mathrm{GA}_{3}$ application increased plant height and average internode length under control and $\mathrm{CuSO}_{4}$ filters, but the response to exogenous $\mathrm{GA}_{3}$ was greater under $\mathrm{CuSO}_{4}$ filters (Fig. $2 \mathrm{~A}$ and $\mathrm{B}$ ). Increasing $\mathrm{GA}_{3}$ concentration did not significantly increase height or average internode length (data not shown). The plant height increase following $0.14 \mathrm{mmGA}_{3}$ application was $24 \%$ under $\mathrm{CuSO}_{4}$ filter compared with $16 \%$ in control plants. $\mathrm{GA}_{3}$-treated plants under $\mathrm{CuSO}_{4}$ filter were shorter $(20 \%)$ than non-GA - -treated plants in control chambers. $\mathrm{GA}_{3}$ increased SER within the first week of application under control and $\mathrm{CuSO}_{4}$ filters, but the effect was reduced with time (Fig.

Table 4. Influence of light quality and irradiance on dry weight (dw) and dry weight partitioning of Dendranthema $\times$ grandiflorum 'Bright Golden Anne'. Measurements were taken 4 weeks after start of irradiation treatment.

\begin{tabular}{|c|c|c|c|c|c|c|}
\hline $\begin{array}{l}\mathrm{CuSO}_{4} \\
\text { concn }^{2}\end{array}$ & $\begin{array}{c}\text { PPF } \\
\text { reduction } \\
(\%)\end{array}$ & $\begin{array}{c}\text { Total shoo } \\
\text { dww }^{\mathbf{y}, x} \\
\text { (g) }\end{array}$ & $\begin{array}{l}\mathrm{Le} \\
\mathrm{dv} \\
\text { (g }\end{array}$ & & $\begin{array}{c}\text { Stem } \\
d w^{x} \\
(g)\end{array}$ & $\begin{array}{c}\text { Root } \\
d w^{x, v} \\
(g)\end{array}$ \\
\hline \multirow[t]{3}{*}{0} & 26 & $2.23 \mathrm{a}$ & $1.60 \mathrm{at}$ & $(72)^{\mathrm{v}}$ & 0.63 a $(28)$ & $0.6 \pm 0.1$ \\
\hline & 36 & $2.30 \mathrm{a}$ & $1.70 \mathrm{a}$ & (74) & 0.60 a (26) & $0.6 \pm 0.1$ \\
\hline & 47 & $2.02 \mathrm{~b}$ & $1.50 \mathrm{~b}$ & (74) & $0.52 \mathrm{~b}(26)$ & $0.5 \pm 0.07$ \\
\hline 4 & 26 & $1.52 \mathrm{c}$ & $1.24 \mathrm{c}$ & $(82)$ & $0.28 \mathrm{c}(18)$ & $0.5 \pm 0.1$ \\
\hline 8 & 36 & $1.21 \mathrm{~d}$ & $1.01 \mathrm{~d}$ & (83) & $0.20 \mathrm{~d}(17)$ & $0.3 \pm 0.1$ \\
\hline 16 & 47 & $1.34 \mathrm{~d}$ & $1.10 \mathrm{~d}$ & (82) & $0.24 \mathrm{~cd}(18$ & $0.3 \pm 0.1$ \\
\hline
\end{tabular}

${ }^{\mathrm{z}}$ See Table 1 for spectral characteristics.

${ }^{\mathrm{y}}$ Total shoot $\mathrm{dw}=$ leaf $\mathrm{dw}+$ stem $\mathrm{dw}$.

'Each number is the mean of 20 plants. Mean comparison within a column by Duncan's multiple range test, $P=0.05$. Means with same letter are not significantly different.

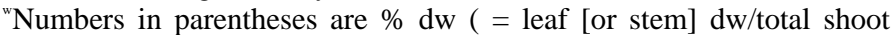
dw) $\times 100$.

"Measured only in one replicate experiment. Each number is the mean of 10 plants. Number followed by mean is standard deviation.

Table 5. Effect of light quality and irradiance on chlorophyll content of Dendranthema $\times$ grandiflorum 'Bright Golden Anne'. Measurements were taken 4 weeks after start of irradiation treatment.

\begin{tabular}{|c|c|c|c|c|c|c|}
\hline \multirow{2}{*}{$\begin{array}{l}\mathrm{CuSO}_{4} \\
\text { concn }^{2} \\
\end{array}$} & \multirow{2}{*}{$\begin{array}{c}\text { PPF } \\
\text { reduction } \\
(\%)\end{array}$} & \multicolumn{4}{|c|}{ Chlorophyll contenty $\left(\mathrm{mg} \cdot \mathrm{g}^{-1} \mathrm{dw}\right)$} & \multirow{2}{*}{$\begin{array}{l}a: b \\
\text { ratio }\end{array}$} \\
\hline & & $\mathrm{a}$ & & b & Total & \\
\hline \multirow[t]{3}{*}{ 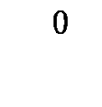 } & 26 & 1.15 & $0.34 \pm$ & \pm & 1.4 & \\
\hline & & & 0.3 & & 1. & \\
\hline & & \pm & $0.30 \pm$ & \pm 0 & $1.27=$ & \\
\hline 4 & $\therefore$ & $1.10 \pm 0.1$ & $0.36 \pm$ & \pm 0 & $1.50 \pm$ & \\
\hline 8 & 3 & $1.04 \pm 0.1$ & $0.35 \pm$ & \pm 0.03 & $1.38 \pm 0.1$ & 3.1 \\
\hline 16 & 47 & $1.07 \pm 0.1$ & $0.35 \pm$ & \pm 0.03 & $1.42 \pm 0.1$ & $3.0=$ \\
\hline
\end{tabular}

${ }^{\mathrm{z}}$ See Table 1 for spectral characteristics.

${ }^{y}$ Each number is mean of 10 plants. Number followed by mean is standard deviation. 

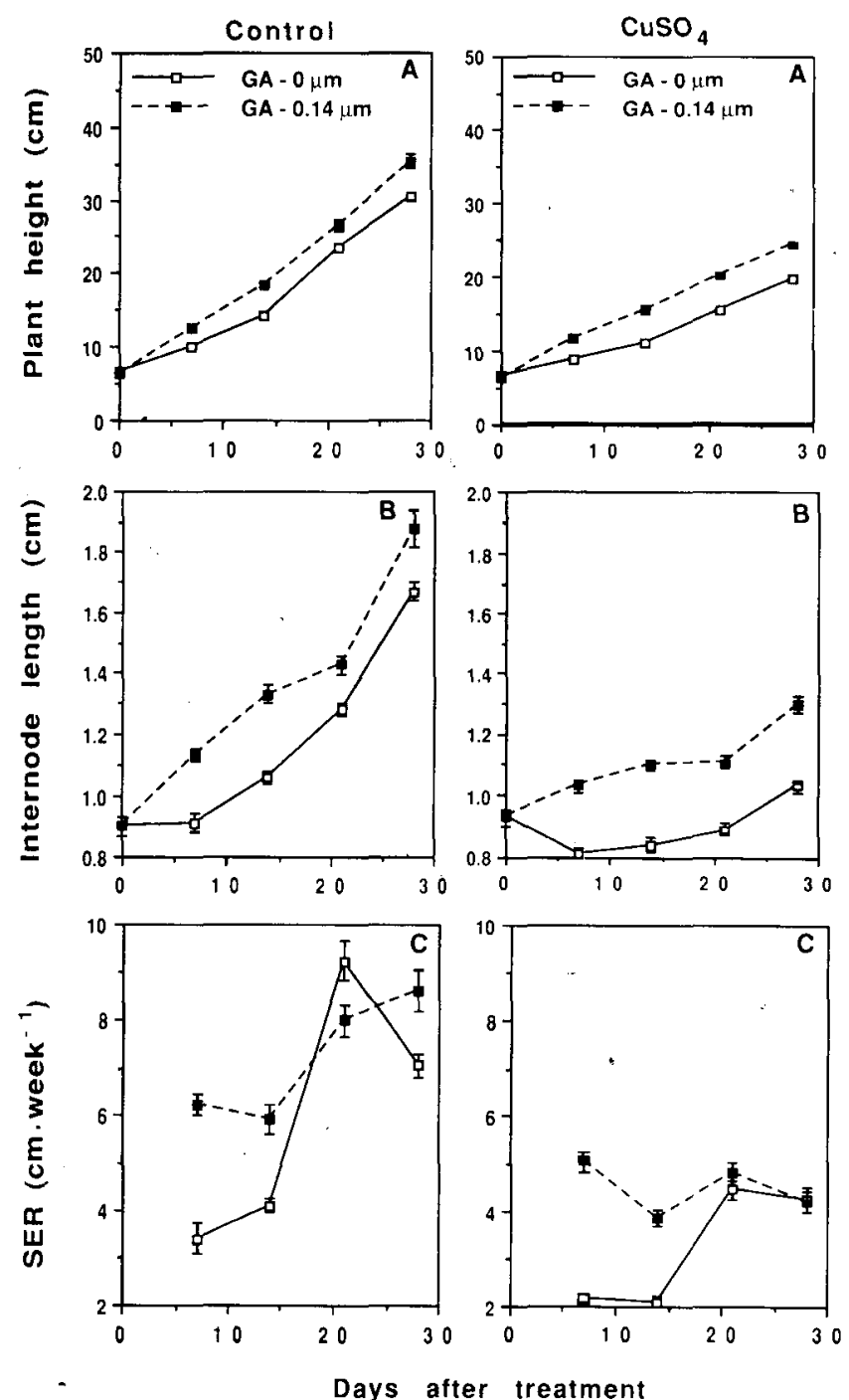

Fig. 2. Plant height (A), average internode length (B), and SER (C) of Dendranthema $\times$ grandiflorum 'Bright Golden Anne' plants treated with $\mathrm{GA}_{3}$ and grown under control (water) or $4 \% \mathrm{CuSO}_{4}$ filters. Vertical bars indicate SE.

2C). $\mathrm{GA}_{3}(0.14 \mathrm{~mm})$ caused $133 \%$ and $82 \%$ increase in SER within the first week after application under $\mathrm{CuSO}_{4}$ and control filters, respectively.

Total LA, LS, and SLW were not affected by the exogenous $\mathrm{GA}_{3}$ application in either irradiation treatment (Table 6). Exogenous $\mathrm{GA}_{3}$ increased LDW and SDW under control and $\mathrm{CuSO}_{4}$ filters (Table 6). Increasing $\mathrm{GA}_{3}$ concentration had no influence on dry weight under any irradiation treatment. $\mathrm{GA}_{3}$ treatment did not alter dry-matter partitioning into leaves and stem in either treatment.

\section{Discussion}

Height reduction under $\mathrm{CuSO}_{4}$ filters was caused by decreased average internode length and SER and, to a lesser extent, by a reduction of node count. In experiments with different spectral filters, a similar reduction in plant height and internode length as with the $\mathrm{CuSO}_{4}$ filters has been reported in a wide range of plants (Benson and Kelly, 1990; McMahon and Kelly, 1990a, 1990b; Mortensen and Strømme, 1987). The height reduction under $\mathrm{CuSO}_{4}$ filters maybe explained by the high $\mathrm{R}$ :
Table 6. Effect of exogenous $\mathrm{GA}_{3}$ application on LA, leaf dry weight (LDW), stem dry weight (SDW), SLW, and LS of Dendranthema $\times$ grandiflorum 'Bright Golden Anne' after 4 weeks of growth under control (water) or $4 \% \mathrm{CuSO}_{4}$ filter.

\begin{tabular}{lllllll}
\hline \hline Treatment & $\begin{array}{c}\text { GA } \\
(\mu \mathrm{M})\end{array}$ & $\begin{array}{c}\text { LA }^{y} \\
\left(\mathrm{~cm}^{2}\right)\end{array}$ & $\begin{array}{c}\text { LDWy } \\
(\mathrm{g})\end{array}$ & $\begin{array}{c}\text { SDW } \\
(\mathrm{g})\end{array}$ & $\begin{array}{c}\mathrm{SLW}^{y} \\
\left(\mathrm{~g} \cdot \mathrm{cm}^{-2}\right)\end{array}$ & $\begin{array}{c}\mathrm{LS}^{\mathrm{y}} \\
\left(\mathrm{cm}^{2}\right)\end{array}$ \\
\hline Control & 0 & 593 & $1.8(72)^{\mathrm{x}}$ & $0.7(28)^{\mathrm{x}}$ & 0.034 & 32.9 \\
& 0.07 & 617 & $2.1(70)$ & $0.9(30)$ & 0.035 & 34.0 \\
& 0.14 & 621 & $2.1(70)$ & $0.9(30)$ & 0.035 & 33.39 \\
$\mathrm{CuSO}_{4}$ & 0 & 479 & $1.3(81)$ & $0.3(19)$ & 0.036 & 26.8 \\
& 0.07 & 547 & $1.5(79)$ & $0.4(21)$ & 0.035 & 29.7 \\
& 0.14 & 514 & $1.5(79)$ & $0.4(21)$ & 0.035 & 28.4 \\
ANOVA & & & & & & \\
Treatment & & $* * *$ & $* * *$ & $* * *$ & $*$ & $* * *$ \\
GA & & NS & $* *$ & $* *$ & NS & NS \\
Linear & & NS & $*$ & $* *$ & NS & NS \\
Quadratic & & NS & NS & NS & NS & NS \\
Treatment & GA & NS & NS & NS & NS & NS \\
\hline
\end{tabular}

${ }^{2}$ Photosynthetic photon flux inside control or $4 \% \mathrm{CuSO}_{4}$ filters was reduced $26 \%$ from natural irradiance in the greenhouse. $\mathrm{R}$ : FR ratio of control and $4 \% \mathrm{CuSO}_{4}$ filters was 1.1 and 3.1, respectively.

${ }^{y}$ Each number is the mean of 10 plants.

${ }^{x}$ Numbers in parentheses are \% dry weight $(=$ leaf [or stem] dw/total shoot dw) $\times 100$.

NS, $* * *, * * *$ Nonsignificant or significant at $P=0.05,0.01$, or 0.001 , respectively.

FR and $\mathrm{B}: \mathrm{R}$ ratio, and high estimated $\phi$ values (amount of phytochrome in $\mathrm{P}_{\mathrm{ff}}$ form relative to total $\mathrm{P}$ ) of the irradiance transmitted through these filters. Irradiance with high $\mathrm{R}:$ FR or B : R ratio has previously been reported to reduce shoot elongation of various species (Mortensen and Strømme, 1987). Stem elongation in response to $\mathrm{R}$ and FR irradiance was thought to be regulated by phytochrome, specifically, the $\phi$ in plants (Smith, 1982). Irradiance high in R relative to FR wavelengths has been reported to inhibit stem elongation of dark-grown maize and pea seedlings (Noguchi and Hashimoto, 1990; Vanderhoef et al., 1979). Although much of the work on light quality on stem elongation has focused on R : FR ratios and phytochrome, recent work by Britz and Sager (1990) with soybean [Glycine $\max ($ L.) Merr.] and sorghum [Sorghum bicolor (L.) Moench.] has shown that light deficient in B wavelengths produced tall plants similar to the effects of high FR irradiance.

Reduction in $\mathrm{LA}$ under $\mathrm{CuSO}_{4}$ filters could be attributed to the smaller leaves, as indicated by unit leaf area and, to a lesser extent, to the small reduction in leaf count. Reduced LS resulted in a more compact appearance to the plants. These results are in agreement with the results of Mortensen and Strømme (1987) who observed a reduction in leaf area under $\mathrm{CuSO}_{4}$ filters. Irradiance with high $\mathrm{R}:$ FR has been reported to reduce leaf area of Aglanoema commutatum Schott. (Di Benedetto and Cogliatti, 1990). Holmes and Smith (1977), however, reported that FR light sources (lower $\phi$ ) reduced leaf size of Cucurbita pepo $\mathrm{L}$. Plants grown under light deficient in B wavelengths have also been shown to have larger individual leaves, suggesting a possible involvement of B light receptors (Britz and Sager, 1990).

The reduced stem elongation and leaf size resulted in lower dry weights for plants grown under $\mathrm{CuSO}_{4}$ filters. Increased dry weight in control plants also could be a result of larger LA, enabling control plants to produce more photosynthate. Reduction of dry weight at low PPF under control and $\mathrm{CuSO}_{4}$ filters may be due to a reduction of photosynthesis, because photosynthesis depends on PPF in the range of 400 to $700 \mathrm{~nm}$.

Alteration of dry-matter partitioning suggests that the trans- 
location of photosynthates may be affected by the quality of light. Hurd (1974) reported that low R : FR irradiance increased stem dry weight of 'Minibelle' tomato plants. Kasperbauer (1987) reported that lowering R : FR increased photosynthate partitioning into shoots and developing seeds of soybean [Glycine $\max (\mathrm{L}$.$) ]. The greater dry matter accumulation into leaves un-$ der $\mathrm{CuSO}_{4}$ filters may reexplained by the higher R: FR and B : R ratio under these treatments. Britz and Sager (1990) reported that plants grown under B wavelength-deficient sources had less translocation of photosynthase out of leaves, thus increasing leaf carbohydrate content. Our filters did not filter out $\mathrm{B}$ irradiance, but $\mathrm{B}: \mathrm{R}$ was increased by removing $\mathrm{R}$ irradiance. Chlorophyll content was increased in plants grown under $\mathrm{CuSO}_{4}$ filters; but chlorophyll a content was not altered, resuiting'in a lower chlorophyll $\mathrm{a}: \mathrm{b}$ ratio than in the control plants. Kasperbauer (1988) reported that high R : FR irradiance altered the chlorophyll structure and decreased the chlorophyll $\mathrm{a}: \mathrm{b}$ ratio. Holmes- and Smith (1977) also reported that light high in $\mathrm{R}$ wavelengths increases chlorophyll content and $\mathrm{a}: \mathrm{b}$ ratio of some plant species.

Plants grown under $\mathrm{CuSO}_{4}$ filters were similar in many respects (e.g., shorter plants and internodes, smaller leaves and leaf area, reduced dry weight, thicker leaves, and increased chlorophyll content) to plants treated with chemical growth retardants (Starman et al., 1989; Wang and Gregg, 1989). Chemical growth retardants are believed to reduce stem elongation through the inhibition of GA biosynthesis and/or action (Graebe, 1987). Since the plants grown under $\mathrm{CuSO}_{4}$ filters had similar characteristics to plants treated with chemical growth inhibitors, reduced chrysanthemum stem elongation by irradiance transmitted through $\mathrm{CuSO}_{4}$ filters may be mediated through differences in hormone synthesis/action, most likely GA.

Tucker (1976) reported that the level of GA-like substances in apical regions was higher in plants treated with FR irradiance. Lockhart (1964) suggested that conversion of GA to the "active form" may be prevented by R irradiance and promoted by FR irradiance. Campell and Bonner (1986) concluded that $3 \beta$-hydroxylation of $\mathrm{GA}_{20}$ (precursor) to $\mathrm{GA}_{1}$ (active form) in dwarf pea seedlings was prevented by $\mathrm{R}$ irradiance and controlled by phytochrome.

A single application of exogenous $\mathrm{GA}_{3}$ to chrysanthemums partially overcame the height and SER reduction caused by irradiance transmitted through $\mathrm{CuSO}_{4}$ filters during the first week of application, suggesting that the reduction of stem elongation under $\mathrm{CuSO}_{4}$ filters may be mediated by changes in GA biosynthesis or action. The effect of a single $\mathrm{GA}_{3}$ application likely diminished with time; the $\mathrm{CuSO}_{4}$-filtered light probably further suppressed GA production/action within the plant to reduce stem elongation. However, further experimentation is needed to determine possible GA involvement on stem elongation under $\mathrm{CuSO}_{4}$ filters.

We conclude that light quality can be used as an alternative means of controlling plant height and producing compact pot chrysanthemum plants. Development of greenhouse material with specific light transmission characteristics would facilitate the use of light quality for plant growth regulation. The effects of light quality on chrysanthemum were similar to those induced by chemical growth retardants and may be mediated through alteration of GA biosynthesis/action. Experiments with various plant species would enhance our knowledge of the possible use of light quality as a means of regulating plant growth in the ornamental plant industry.

\section{Literature Cited}

Benson, J. and J.W. Kelly. 1990. Effect of copper sulfate filters on growth of bedding plants. HortScience 25:1144. (Abstr.)

Britz, S.J. and J.C. Sager. 1990. Photomorphogenesis and photoassimilation in soybean and sorghum grown under broad spectrum or bluedeficient light sources. Plant Physiol. 94:448-454.

Campell, B.R. and B.A. Bonner. 1986. Evidence for phytochrome regulation of gibberellin $\mathrm{A}_{40} 3 \beta$-hydroxylation in shoots of dwarf (lle) Pisum sativum L. Plant Physiol. 82:909-915.

Decoteau, D.R. and L.E. Craker. 1984. Abscission: Characterization of light control. Plant Physiol. 75:87-89.

Deregibus, V. A., R.A. Sanchez, and J.J. Casal. 1983. Effects of light quality on tiller production in Lolium spp. Plant Physiol. 72:900-902.

Di Benedetto, A.H. and D.H. Cogliatti. 1990. Effects of light intensity and quality on the obligate shade plantAglaonema commutatum. 1. Leaf size and leaf shape. J. Hort. Sci. 65:689-698.

Graebe, J.E. 1987. Gibberellin biosynthesis and control. Annu. Rev. Plant Physiol. 38:419-65.

Heins, R. and J. Erwin. 1990. Understanding and applying DIF. Greenhouse Grower 8(2):73-78.

Holmes, M.G. and H. Smith. 1977. The function of phytochrome in the natural environment- IV. Light quality and plant development. Photothem. Photobiol. 25:551-557.

Hurd, R.G. 1974. The effect of an incandescent supplement on the growth of tomato plants in low light. Ann. Bet. 38:613-623.

Kasperbauer, M.J. 1987. Far-red light reflection from green leaves and effects on phytochrome-mediated assimilate partitioning under field conditions. Plant Physiol. 85:350-354.

Kasperbauer, M.J. 1988. Phytochrome involvement in regulation of the photosynthetic apparatus and plant adaptation. Plant Physiol. Biochem. 26:519-524.

Lockhart, J.A. 1964. Physiological studies on light sensitive stem growth. Planta 62:97-1 15.

McMahon, M.J. and J.W. Kelly. 1990a. Control of poinsettia growth and pigmentation by manipulating light quality. HortScience 25:1068. (Abstr.)

McMahon, M.J. and J.W. Kelly. 1990b. Influence of spectral filters on height, leaf chlorophyll, and flowering of Rosa $\times$ hybrida 'Meirutral'. J. Environ. Hort. 8:209-211.

Moran, R. 1982. Formulae for determination of chlorophyllous pigments extracted with N,N-dimethylformamide. Plant Physiol. 69:1376-1381.

Moran, R. and D. Porath. 1980. Chlorophyll determination in intact tissues using N, N-dimethylformamide. Plant Physiol. 65:478-479.

Mortensen, L.M. and E. Strømme. 1987. Effects of light quality on some greenhouse crops. Scientia Hort. 33:27-36.

Noguchi, H. and T. Hashimoto. 1990. Phytochrome mediated synthesis of novel growth inhibitors. A $-2 \alpha$ and $\beta$, and dwarfism in peas. Planta 181:256-262.

Sager, J. C., W.O. Smith, J.C. Edwards, and K.L. Cyr. 1988. Photosynthetic efficiency and phytochrome photoequilibria determination using spectral data. Transactions of Amer. Soc. Agr. Eng. 31: 1882-1887.

Smith, H. 1982. Light quality, photoperception, and plant strategy. Annu. Rev. Plant Physiol. 33:481-518.

Starman, T. W., J. W. Kelly, and H.B. Pemberton. 1989. Characterization of ancymidol effects on growth and pigments of Helianthus annum cultivars. J. Amer. Soc. Hort. Sci. 114:427-430.

Tucker, D.J. 1975. Far-red light as a suppressor of side shoot growth in the tomato. Plant Sci. Lett. 5:127-130.

Tucker, D.J. 1976. Effects of far-red light on the hormonal control of side shoot growth in tomato. Ann. Bet. 40:1033-1042.

Tucker, D.J. and T.A. Mansfield. 1973. Apical dominance in Xanthium strumarium: A discussion in relation to current hypotheses of correlative inhibition. J. Expt. Bet. 24:731-740.

Vanderhoef, L. N., P.H. Quail, and W.R. Briggs. 1979. Red light-inhibited mesocotyl elongation in maize seedlings. Plant Physiol. 63: 1062-1067.

Wang, Y.T. and L.L. Gregg. 1989. Uniconazole affects vegetative growth, flowering, and stem anatomy of hibiscus. J. Amer. Soc. Hort. Sci. 114:927-932. 